\title{
Reexamination of the Effect of Endotoxin on Cell Proliferation and Transfection Efficiency
}

BioTechniques 29:610-619(September 2000)

\author{
Kimberly A. Butash, Pachai \\ Natarajan, Alice Young and \\ Donna K. Fox \\ Life Technologies, Rockville, \\ MD, USA
}

\section{INTRODUCTION}

Endotoxin or lipopolysaccharide (LPS) is a major component of gramnegative bacterial cell walls that can have complex effects on mammalian systems, including nonspecific activation of the immune system, stimulation of cytokine overproduction and induction of the characteristic shock syndrome associated with bacterial infections (1). LPS is a contaminant in plasmid DNA preparations, which is a major concern for researchers using plasmid DNA for gene therapy in vivo or in other studies (19). Endotoxin contamination is also a concern for in vitro studies and has been reported to markedly lower transgene expression as a function of the transfection method and choice of mammalian cell line (17). However, it is unclear if the negative effect of endotoxin on mammalian cell transfection is a result of effects on cell viability (4) or an overall decrease in transfection efficiency. The results shown here clarify these points by examining endotoxin effects on cell proliferation and transfection efficiency, using a number of different mammalian cell lines that are commonly used for transfection. We also investigate the efficiency of transfection using preparations of plasmid DNA isolated from $E$. coli by various purification methods and com pare the results to the data obtained from the endotoxin dose-response studies.

\section{MATERIALS AND METHODS}

All cell lines and reagents are products from Life Technologies (Rockville, MD, USA) unless otherwise indicated. Nine different cell lines were used: HeLa (ATCC, Manassas, VA, USA), a human cervical carcinoma cell line (2); COS-7L, an immortalized African green monkey kidney cell line (7); CHO-S and CHO K1 (ATCC), Chinese hamster ovary cell lines (16); HEK293F, a human embryonic kidney cell line (3); and PC-12 (ATCC), a rat pheochromocytoma cell line (8). The cell lines were chosen because they are commonly used for transfection studies and for production of recombinant proteins. K562 (ATCC), a human myelogenous leukemia cell line (9), and Jurkat (ATCC), a human $\mathrm{T}$ cell lymphoma cell line (6), were chosen because they are grown in suspension; Huh-7, a human hepatocarcinoma cell line (11), has been reported to be sensitive to endotoxins (18).

HeLa cells were grown in DMEM supplemented with $10 \%$ FBS. CHO-S (grown as adherent cells) and $\mathrm{CHO}-\mathrm{K} 1$ were grown in DMEM supplemented with $10 \%$ FBS, 0.1 mM NEAA (nonessential amino acids) and $0.1 \%$ L-proline. COS-7L and HEK293F were grown in DMEM supplemented with $10 \%$ FBS and 0.1 mM NEAA, then plated onto polylysine-coated plates. PC-12 cells were grown on DMEM supplemented with 5\% FBS, $10 \%$ heatinactivated horse serum and $0.1 \mathrm{mM}$ NEAA. When PC-12 cells were plated for transfection, $50 \mathrm{ng} / \mathrm{mL}$ nerve growth factor (NGF) are added during plating and growth after transfection. Huh-7 cells were grown in RPMI 1640 Supplemented with $10 \%$ FBS. K562 and Jurkat cells were grown in RPMI 1640 supplemented with $10 \%$ FBS and $1 \%$ antibiotic/antimycotic.

The effect of endotoxin on cell proliferation was measured using alamarBlue $^{\mathrm{TM}}$ (Trek Diagnostics, Westlake, $\mathrm{OH}$, USA) according to the manufacturer's protocol. Cells were plated into 96-well plates at the indicated densities. 
Immediately after plating, endotoxin (E. coli 055:B5; BioWhittaker, Walkersville, MD, USA) was added. Cells were allowed to grow at $37^{\circ} \mathrm{C}$. The alamarBlue was added $24 \mathrm{~h}$ after plating, and reduction of the dye was measured
4-6 $\mathrm{h}$ after the addition by absorbance at 570 and $600 \mathrm{~nm}$. The amount of reduced alamarBlue is proportional to the number of viable cells (5).

Transfections were performed according to the manufacturer's recom-
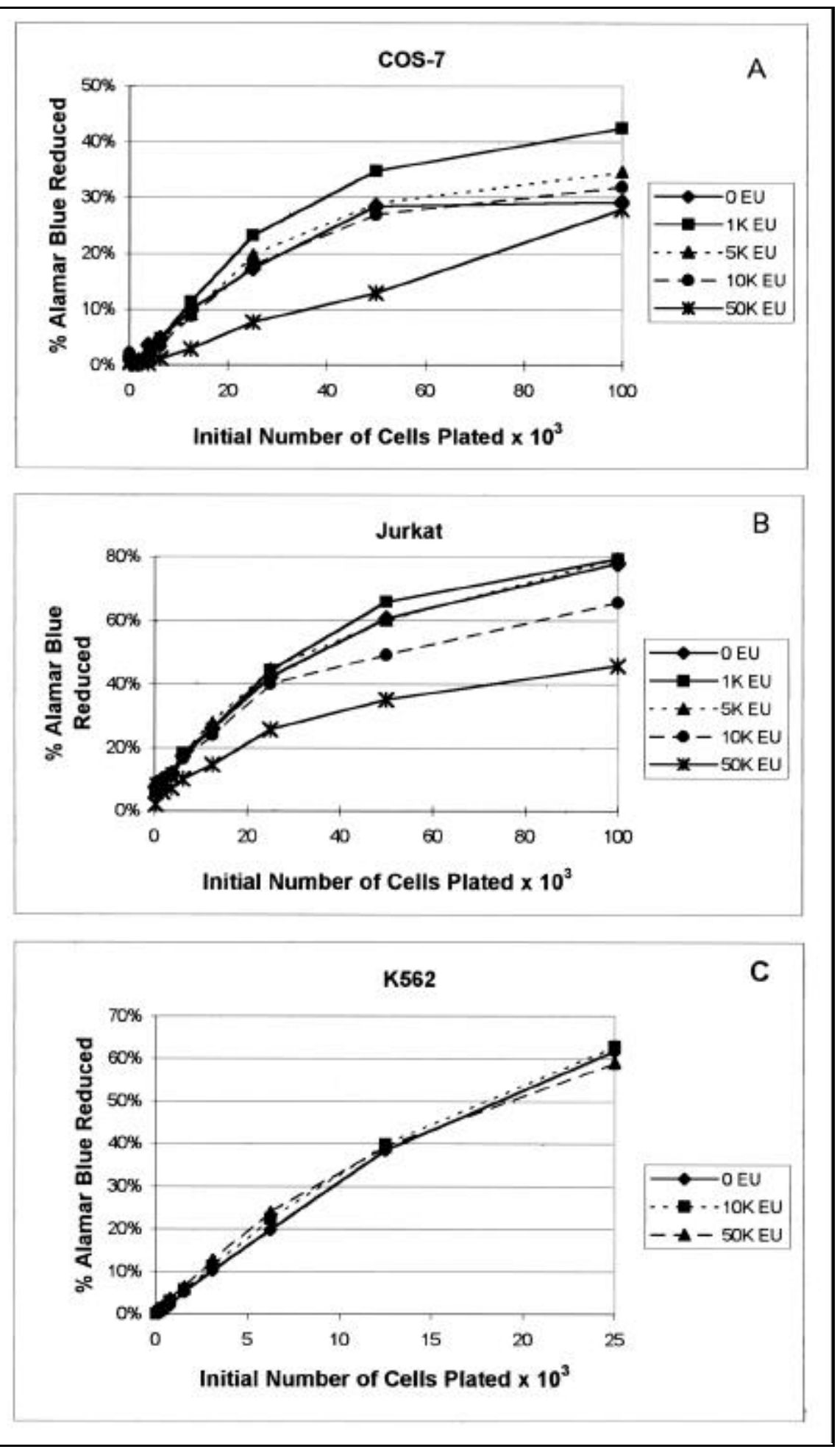

Vol. 29, No. 3 (2000)

mended protocols. Cells were plated at the indicated density the day before transfection. The following transfection reagents were used: LIPOFECTIN ${ }^{\circledR}$, LIPOFECTAMINE ${ }^{\mathrm{TM}}$, LIPOFECTAMINE PLUS $^{\mathrm{TM}}$ and LIPOFECTAMINE ${ }^{\mathrm{TM}} 2000$. For each cell line, one of these transfection reagents was used after determining it was the optimal transfection reagent for transfection of that cell line. Expression of $\beta$-galactosidase ( $\beta$-gal) was measured by hydrolysis of $\mathrm{pNPG}$ (p-nitrophenyl- $\beta$-gal) (13) or by in situ staining of the cells for enzymatic activity (15). Transfection efficiency is reported as either $\mathrm{ng} \beta-\mathrm{gal} / \mathrm{cm}^{2}$ culture dish area or percentage of cells stained. Data shown are the average of at least three transfections.

To minimize sources of variability, only one plasmid containing the $\beta$-gal gene under control of a CMV promoter (pCM ß; Clontech Laboratories, Palo Alto, CA, USA) and one strain of $E$. coli (DH10B; Life Technologies) were used for these experiments. DH10B cells containing the plasmid were grown as recommended for each purification method. Briefly, $3 \mu \mathrm{L}$ of a glycerol stock was inoculated into $3 \mathrm{~mL} \mathrm{LB}$ and grown for $4 \mathrm{~h}$ at $37^{\circ} \mathrm{C}$. This culture was then used to inoculate $500 \mathrm{~mL} \mathrm{LB}$ containing $100 \mu \mathrm{g} / \mathrm{mL}$ ampicillin in a 2.8-L baffled Fernbach flask. Cells were grown to an $\mathrm{OD}_{800}$ of 2.0, harvested by centrifugation and the plasmid purified using either the CONCERT ${ }^{\mathrm{TM}}$ High Purity Plasmid Maxiprep System (Life Technologies), EndoFree ${ }^{\mathrm{TM}}$ Plasmid Maxi Kit (Qiagen, Valencia, CA, USA), density gradient centrifugation in $\mathrm{CsCl}(14)$ or an abbreviated alkaline lysis method (14) where cell lysate was clarified by centrifugation $(\geq 15000 \times g)$ and the DNA precipitated directly from the supernatant by the addition of salt and ethanol. Comparisons of the different DNA purification methods were done using aliquots from the same bacterial culture. Levels of endotoxin in the

Figure 1. Effect of endotoxin on cell proliferation. (A) COS-7, (B) Jurkat and (C) K562 cells were plated to 96-well plates at the indicated densities. After $1 \mathrm{~h}$, various amounts of endotoxin $(E$. coli 055:B5) were added and growth continued at $37^{\circ} \mathrm{C}$ for $24 \mathrm{~h}$. Cell proliferation/viability was measured by reducing alamarBlue as described in Materials and Methods. Each data point represents an average of $n \geq 3$ replicates. 


\section{Research Report}

plasmid DNA samples were measured using the chromogenic limulus amebocyte assay (QCL-1000 Chromogenic LAL kit; BioWhittaker) with E. coli 055:B5 LPS as the standard. One EU is equivalent to $1 \mathrm{ng}$ LPS.

\section{RESULTS}

The effect of bacterial endotoxin $(\leq$ $50000 \mathrm{EU} / \mathrm{well}$ ) on proliferation and viability of the various cell lines was measured as a function of initial cell plating density so that any effects on cell populations growing at various levels of confluency could be observed. Figure 1 shows data for COS- $7 \mathrm{~L}, \mathrm{Ju}-$ rkat and K562 cells, respectively. At lower endotoxin amounts (i.e., 1000-5000 EU/well), a slight mitogenic effect was reproducibly observed in COS-7L and Jurkat but not in K562 cells. Significant decreases in cell proliferation were observed when much higher doses of endotoxin were added, but the threshold of this effect was not the same for every cell line tested. For example, K562 cells did not display any sensitivity up to $50000 \mathrm{EU}$, but decreases in proliferation were seen in COS-7 cells at this same dose. Jurkat cells displayed sensitivity at lower thresholds of $10000 \mathrm{EU}$ with further decreases at 50000 EU. Huh-7 cells behaved similarly, with endotoxin levels of greater than $25000 \mathrm{EU}$ required for decreases in cell proliferation/viability (data not shown). We also performed transfections by including plasmid DNA and transfection reagent along with the various endotoxin doses ( $\leq$ $50000 \mathrm{EU} / w e l l)$ and did not observe any significant alterations in the proliferation data for each of the cell lines tested (data not shown).
We examined the effect of bacterial endotoxins on the transfection efficiency of plasmid DNAs in various cell lines. Figure 2 shows the effect of endotoxin on transfection efficiency in COS7L, CHO-S and Huh-7 cells, respectively. In these experiments, pCMV $\beta$ with increasing amounts of bacterial endotoxin up to $20000 \mathrm{EU} / \mu \mathrm{g}$ DNA was used for transfections. In COS-7L and CHO-S cells, decreases in transfection efficiency were observed at endotoxin doses higher than $2000 \mathrm{EU} / \mu \mathrm{g}$ DNA. In both cases, transfection efficiency was decreased by nearly $50 \%$ when 15000 EU/ $\mu \mathrm{g}$ DNA were added.

These observations were not dependent on choice of transfection lipid because transfection with another transfection reagent in these same cell lines gave similar results (data not shown). For the other cells lines tested (K562, PC-12, HeLa, COS-7L, CHO-K1, CHO-S and
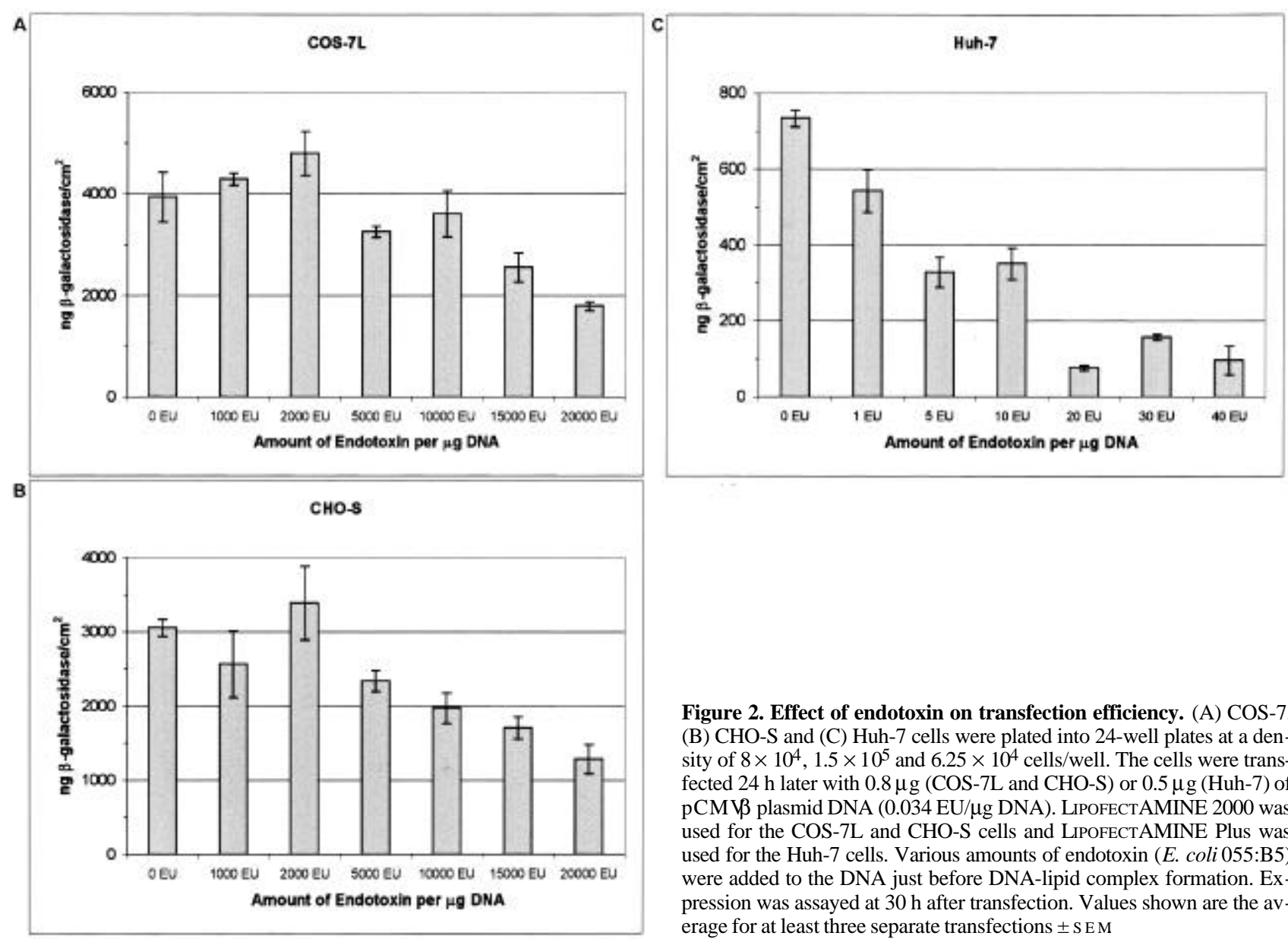

Figure 2. Effect of endotoxin on transfection efficiency. (A) COS-7, (B) CHO-S and (C) Huh-7 cells were plated into 24-well plates at a density of $8 \times 10^{4}, 1.5 \times 10^{5}$ and $6.25 \times 10^{4}$ cells/well. The cells were transfected $24 \mathrm{~h}$ later with $0.8 \mu \mathrm{g}$ (COS-7L and CHO-S) or $0.5 \mu \mathrm{g}$ (Huh-7) of pCM $§$ plasmid DNA (0.034 EU/ $\mu \mathrm{g}$ DNA). LIPOFECTAMINE 2000 was used for the COS-7L and CHO-S cells and LipoFECTAMINE Plus was used for the Huh-7 cells. Various amounts of endotoxin (E. coli 055:B5) were added to the DNA just before DNA-lipid complex formation. Expression was assayed at $30 \mathrm{~h}$ after transfection. Values shown are the average for at least three separate transfections \pm SEM 


\section{Research Report}

HEK293F), decreases in transfection efficiency were observed at endotoxin doses higher than 2000-5000 EU/ $\mu \mathrm{g}$ DNA. However, with Huh-7 cells (Figure $2 \mathrm{C}$ ), we observed that much lower doses of added bacterial endotoxin decreased transfection efficiency. In this cell line, $5 \mathrm{EU} / \mu \mathrm{g}$ DNA dramatically reduced transfection efficiencies to $50 \%$ of the control. This was also observed when the Huh-7 cells in the various treatment groups were stained for $\beta$-gal expression (Figure 3 ).

Next, we examined the effect of the plasmid purification method on transfection efficiency. The plasmid pCMY $\beta$ was purified from DH10B E. coli using an abbreviated alkaline lysis mini-prep method, a $\mathrm{CsCl}_{2}$ density gradient $(2 \times$ banding), the anion-exchange technology (CONCERT system) and endotoxinfree purification system as described in
Materials and Methods.

The levels of endotoxin in these DNA preparations were as follows: crude alkaline lysis mini-prep method (6600 EU/ $\mu$ g DNA); $2 \times$-banded $\mathrm{CsCl}_{2}$ gradient and endotoxin-free method (both < $0.001 \mathrm{EU} / \mu \mathrm{g}$ DNA); and the anion-exchange method $(0.034 \mathrm{EU} / \mu \mathrm{g}$ DNA). The range of endotoxin contam ination in plasmid DNA preparations from $\mathrm{DH} 10 \mathrm{~B}$ cells was $0.01-0.2 \mathrm{EU} / \mu \mathrm{g}$ DNA when cells were purified by the CONCERT System. These values could increase with lower copy number plasmids. Also, the levels of endotoxin contamination depend on the purification system used. Endotoxin levels in the DNA purified by the other anion-exchange system tested in this report are 50 times higher $(0.5-10 \mathrm{EU} / \mu \mathrm{g})$. Plasmid DNA purified by the CONCERT system from $E$. coli $\mathrm{DH} 5 \alpha$ cells generally had lower levels of endotoxin contamination (data not shown).

Data for COS-7L, CHO-K1, CHOS, HEK293F and Huh-7 cells are shown in Figure 4. Maximal transfection efficiencies were observed with plasmid DNA purified by the anion exchange and endotoxin-free methods. This observation was expected because the levels of bacterial endotoxin contamination in these preparations are significantly lower than the threshold value needed to either inhibit transfection (Figure 2) or cell proliferation (Figure 1). As a control for the detection of inhibition, $16000 \mathrm{EU}$ were added to the plasmid DNA purified by anion-exchange resin. This addition resulted in a significant reduction in transfection efficiency for each cell line tested, which is in agreement with the observations shown in Figure 2. The lower transfection effi-

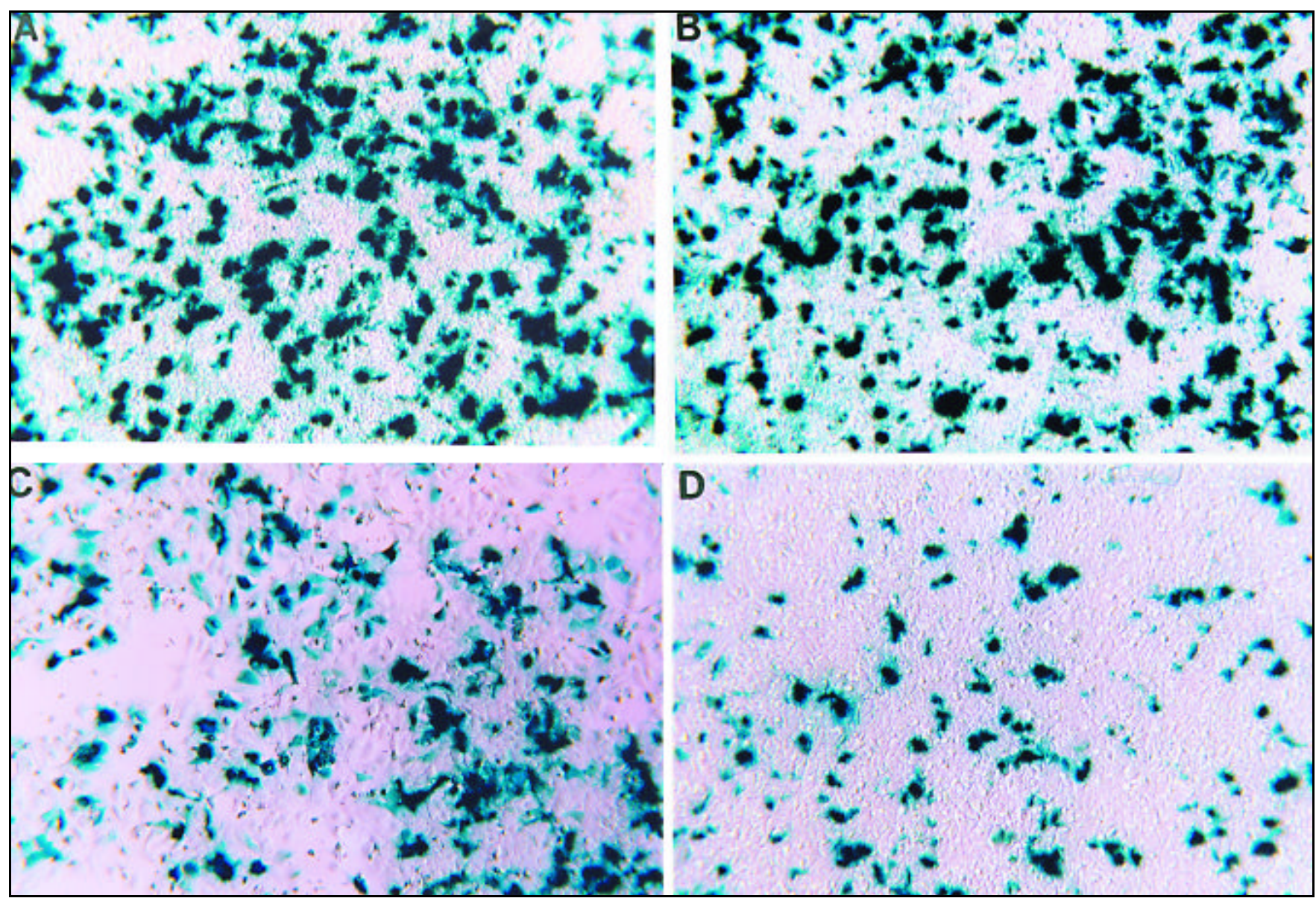

Figure 3. Effects of endotoxin on transfection efficiency in Huh-7 cells. Huh-7 cells were transfected as in Figure 2 . $\beta$-gal was assayed in situ $24 \mathrm{~h}$ after transfection as described (17). (A) No additional endotoxin added; (B) 1 EU/ $\mu \mathrm{g}$ DNA added; (C) 5 U/ $\mu \mathrm{g}$ DNA added; (D) 10 EU/ $\mu \mathrm{g}$ DNA added. The percentage of total cells that stained for enzymatic activity were $87.3 \pm 0.5,88.9 \pm 0.81,63.7 \pm 12.6$ and $13.3 \pm 1.0$ for panels A, B, C and D, respectively. Between 400 and 600 cells were counted in each treatment group. 


\section{Research Report}

ciency of the DNA purified by $2 \times \mathrm{CsCl}_{2}$ has been suggested to be caused by differing physical conformations of the DNA purified by this method (17).

It is noteworthy that DNA purified by the crude alkaline lysis method yielded transfection efficiencies lower than what would be expected from endotoxin contamination levels of $6600 \mathrm{EU} / \mathrm{\mu g}$ DNA for COS-7L (Figure 2A) and

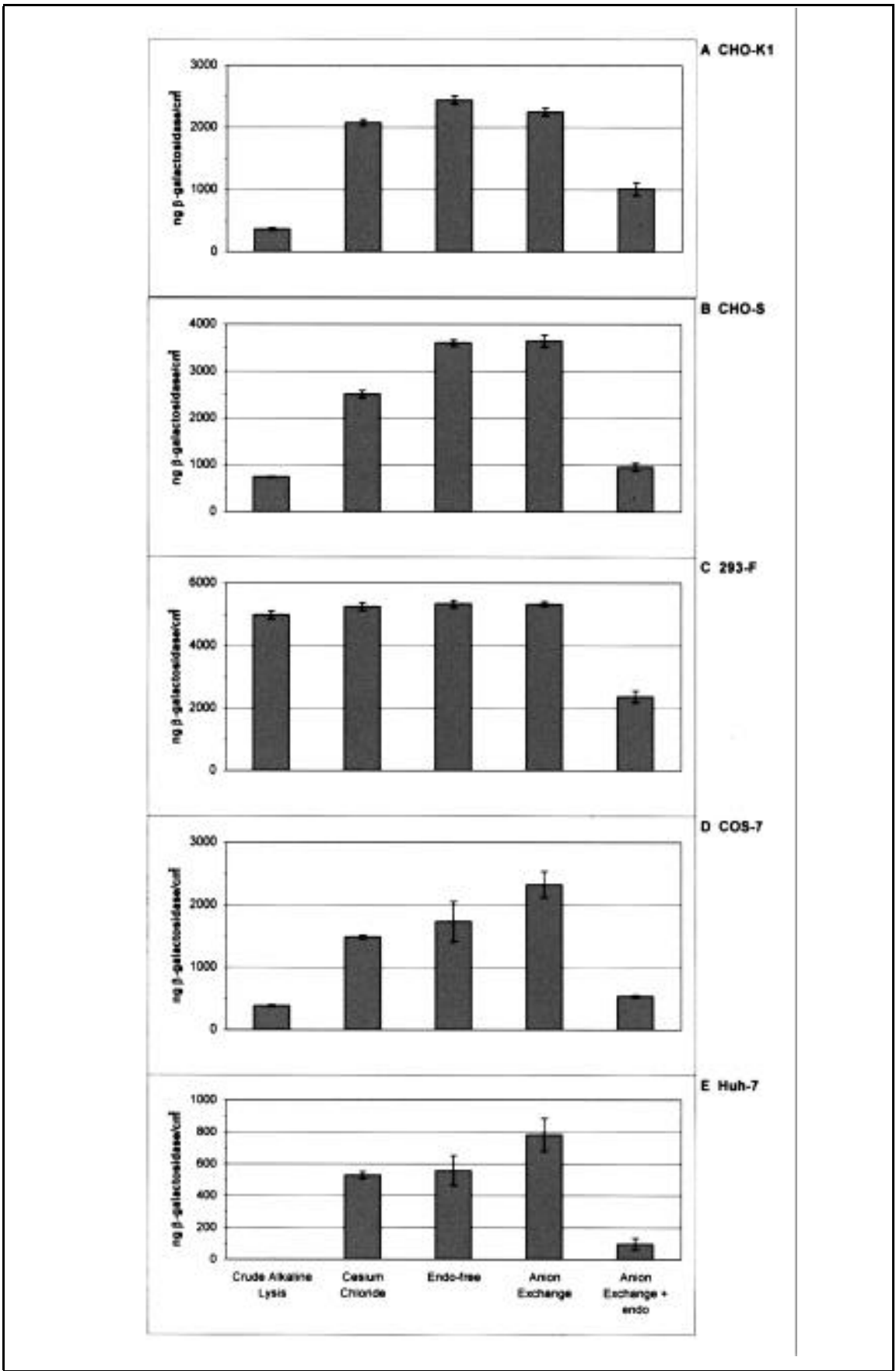

Figure 4. Effect of plasmid purification method on transfection efficiency. (A) CHO-K1, (B) CHO S), (C) HEK293F, (D) COS-7L and (E) Huh-7 cells were plated into 24-well plates at the following densities per well: $6.25 \times 10^{4}, 8 \times 10^{4}, 2 \times 10^{5}, 1.5 \times 10^{5}$ and $2 \times 10^{5}$, respectively. pCMYß plasmid DNA was purified from bacterial cultures by different methods as indicated. When endotoxin was added, $16000 \mathrm{EU}$ (A-D) and 40 EU (E) were added. Transfection of plasmid DNA into cells was done using LIPOFECTAMINE 2000 for all of the cell lines except for Huh-7 which received LIPOFECTAMINE PLUS. Expression of $\beta$-gal was assayed $30 \mathrm{~h}$ after transfection as described. Values shown are the average \pm SEM $(n \geq 3)$. 


\section{Research Report}

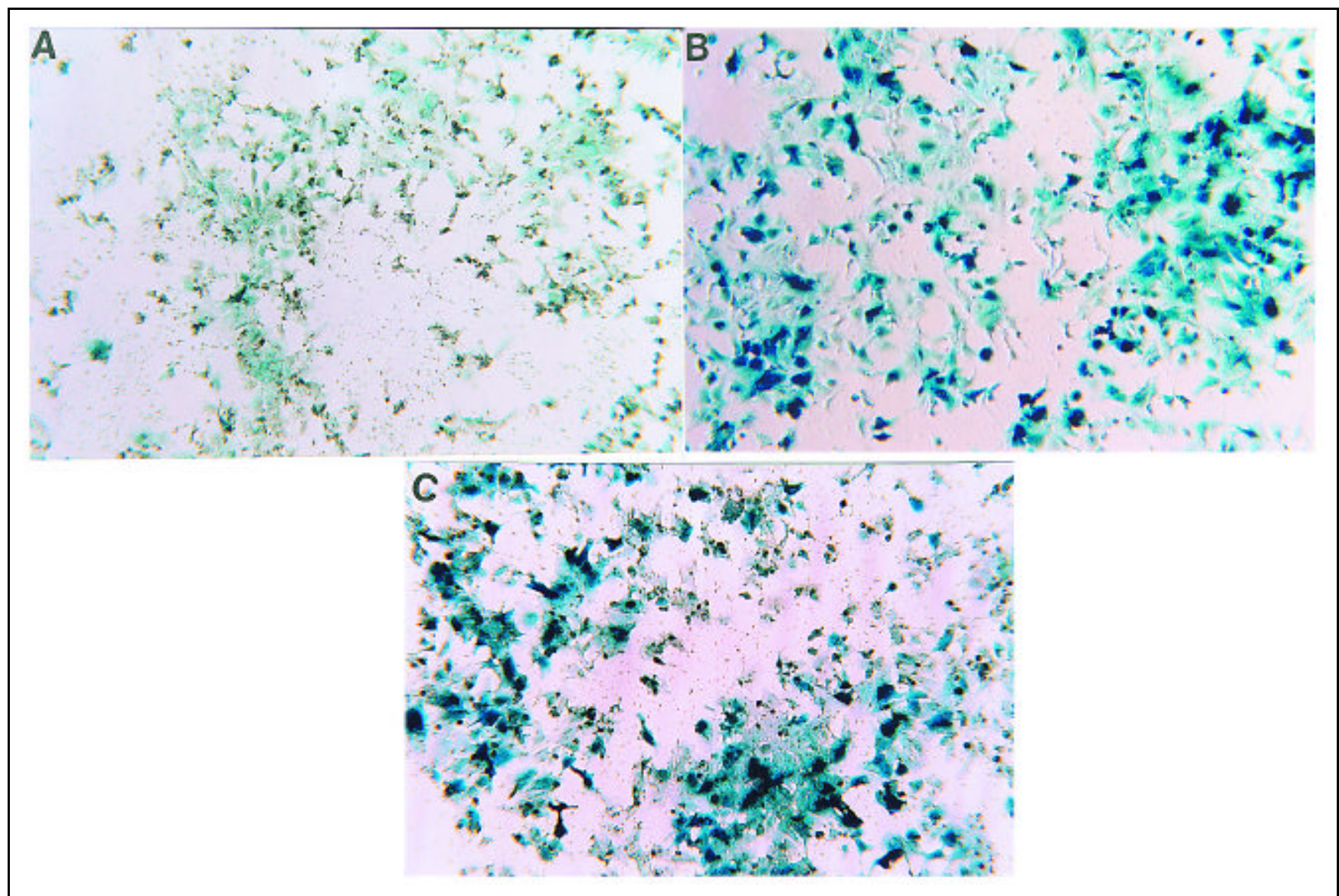

Figure 5. Effect of plasmid purification method on transfection efficiency in Huh-7 cells. Huh-7 cells were plated into 24-well plates and transfected as described in Figure 3 using pCMY $\beta$ purified by crude alkaline lysis (A), anion-exchange (B) or endotoxin-free (C) purification methods. Expression of $\beta$-gal was determined by in situ staining of the cell monolayers $30 \mathrm{~h}$ after transfection.

CHO-S cells (Figure 2B), but not for HEK293F cells. The magnitude of this inhibitory effect in some cell lines could be a result of other contaminants, such as RNA and protein in the DNA (17).

The same experiment was performed using Huh-7 cells that, according to observations in Figure $2 \mathrm{C}$ and Figure 3, display a pronounced sensitivity to bacterial endotoxins. As shown in Figure 4E, transfection of these cells using plasmid DNA purified by a highly efficient anion-exchange resin and endotoxin-free methodology provided maximal levels of transfection efficiency. Again, this result is expected because the level of contaminating bacterial endotoxin is below the threshold of 1-5 EU/Mg DNA (Figure 2C). The plasmid DNA purified using the crude alkaline lysis method resulted in no detectable enzyme activity, which is likely a result of higher levels of contami- nating endotoxins. Figure 5 shows similar results in an experiment where the cells were stained for $\beta$-gal activity.

\section{DISCUSSION}

We determined endotoxin effects on transfection using several cell lines that are frequently used for plasmid transfection studies and protein overexpression. We observed that endotoxin levels greater than $2000 \mathrm{EU} / \mu \mathrm{g}$ DNA are required to significantly inhibit transfection for most of the cell lines tested. These results differ from some earlier reports and may be a result of the low levels of transfection that were obtained even with highly purified DNA. Huh-7 cells are the only exception to these conclusions and display a more pronounced sensitivity to bacterial endotoxin.

Also, we found no correlation be- tween inhibition of transfection by endotoxin and a decrease in cell viability/proliferation. For all cell lines tested except HeLa, levels of bacterial endotoxin $\geq$ $10000 \mathrm{EU}$ were needed to significantly inhibit cell proliferation and decrease viability. These results were obtained even under transfection conditions under which plasmid DNA and transfection reagents were added to the assay. It appears that for most of the cell lines tested, at least 5- to 25-fold higher levels of bacterial endotoxin are needed to significantly inhibit cell proliferation as com pared to levels needed to markedly reduce transfection efficiency.

We prepared plasmid DNA using purification methods that resulted in DNA preparations with various levels of bacterial endotoxin contamination. With the exception of the crude alkaline lysis mini-prep method, the measured endotoxin levels were all much 
lower than that required to significantly inhibit either cell proliferation or transfection efficiency. Specifically, the transfection results using anion-exchange and endotoxin-free purified DNA were indistinguishable in the cell lines tested. It may not be necessary to purify DNA using a system that contains endotoxin-free purification com ponents and protocols because the use of a highly efficient anion-exchange, resin-based system provides sufficiently pure DNA without the labor associated with $\mathrm{CsCl}_{2}$ density gradients.

Likewise, Huh-7 cells, which are more sensitive to endotoxin contamination than the other cells in this study (Figure 3), do not appear to require plasmid DNA preparations purified using endotoxin-free DNA methods. It is im portant to note that not all commercially available anion-exchange purification systems are equally efficient in reducing endotoxin. Also, plasmid DNA preparations with low levels of bacterial endotoxin $(<0.001 \mathrm{EU} / \mu \mathrm{g}$ DNA), designated endotoxin-free may be required for in vivo studies or for in vitro transfection work using unique cell lines with endotoxin-regulated promoters $(1,10,12)$ or endotoxin-responsive elements.

We conclude that for the cell lines commonly used for in vitro transfection studies and those tested here, it appears that endotoxin-free quality DNA is not necessary. Plasmid DNA purified using an anion-exchange resin is adequate and does not inhibit cell proliferation and transfection efficiency.

\section{ACKNOWLEDGMENTS}

The authors wish to thank Ms. Barbara Flynn for technical assistance with endotoxin assays, Dr. Sanjeev Gupta (Albert Einstein College of Medicine) for Huh-7 cells and Drs. Larry Mertz, Timothy Fawcett, Val Ciccarone, Pam Hawley-Nelson and Robert Blakesley for helpful discussions.

\section{REFERENCES}

1.Brade, H., S.M. Opal, S.N. and D.C. Morrison (Eds.) 1999. Endotoxin in Health and Disease. Marcel Dekker, New York.

2.Chen, T.R. 1988. Re-evaluation of HeLa, HeLa S3, and Hep-2 karyotypes. Cytogenet.
Cell Genet. 48:19-24

3.Ciccarone, V., Y. Chu, K. Schifferli, J.P Pichet, P. Hawley-Nelson, K. Evans, L. Roy and S. Bennett. 1999. LipofectAMINE ${ }^{\mathrm{TM}}$ 2000 reagent for rapid efficient transfection of eukaryotic cels. FOCUS 21:54-55.

4.Cotten, M., A. Baker, M. Saltik, E. Wagner and M. Buschle. 1994. Lipopolysaccharide is a frequent contaminant of plasmid DNA preparations and can be toxic to primary human cells in the presence of adenovirus. Gene Ther. 1:239-246.

5.Fields, R.D. and M.V. Lancaster. 1993. Dual-attribute continuous monitoring of cell proliferation/cytotoxicity. Am. Biotechnol. Lab. March 1 1:48-50.

6.Gillis, S. and J. Watson. 1980. Biochemical and biological characterization of lymphocyte regulatory molecules. V. Identification $\mathrm{f}$ an interleukin 2-producing human leukemia T cell line. J. Exp. Med. 152:1709-1719.

7.Graham, F.L., J. Smiley, W.C. Russell and R. Naim. 1977. Characteristics of a human cell line transformed by DNA from human adenovirus type 5. J. Gen. Virol. 36:59-72.

8.Greene, L. and A.S. Tischler. 1976. Establishment of.noradrenergic clonal line of rat adrenal pheochromocytoma cells which respond to nerve growth factor. Proc. Natl. Acad. Sci. USA 73:2424-2428.

9.Lozzio, B.B. and C.B. Lozzio. 1979. Properties and usefulness of the original K-562 hu- man myelogenous leukemia cell line. Leuk. Res. 3:363-370.

10.Luss, H., R.K. Li, R.A. Shapiro, E. Tzeng, F.X. McGowan, T. Yoneyama, K. Hatakeyama, D.A. Geller et al. 1997. Dedifferentiated human ventricular cardiac myocytes express inducible nitric oxide sSynthase mRNA but not protein in response to IL-1, TNF, IFN, and LPS. J. Mol. Cell Cardiol. 29:1153-1165.

11.Nakabayashi, H., K. Taketa, K. Miyano, T. Yamane and J. Sato. 1982. Growth of human hepatoma cell lines with differentiated functions in chemically defined medium. Cancer Res 42:3858-3863.

12.Raetz, C.R.H., R.J. Ulevitch, S.D. Wright, C.H. Sibley, A. Ding and C.F. Nathan. 1991. Gram-negative endotoxin: an extraordinary lipid with profound effects on eukaryotic signal transduction. FASEB J. 5:2652-2660.

13.Sambrook, J., E.F. Fritsch and T. Maniatis. 1989. Expression of cloned genes in cultured mammalian cells. p. 16.66. In Molecular Cloning, 2nd Ed., CSH Laboratory Press, Cold Spring Harbor, NY

14.Sambrook, J., E.F. Fritsch and T. Maniatis. 1989. Plasmid Vectors 1.25, 1.42-1.44. In Molecular Cloning, 2nd Ed. CSH Laboratory Press, Cold Spring Harbor, NY.

15.Sanes, J.R., J.L. Rubenstein, J.F. Nicolas. 1986. Use of a recombinant retrovirus to study post-implantation cell lineage in mouse em bryos EMBO J. 5:3133-3342.

16.Schifferli, K., J. Jessee and V. Ciccarone. 1999. Transfection of suspension cultures of CHO cells. FOCUS 21:16-17.

17.Weber, M., K. Möller, M. Welzcek and J. Schorr. 1995. Effects of lipopolysaccharide on transfection efficiency in eukaryotic cells. BioTechniques 19:931-939.

18. Weber, M., K. Möller and J. Schorr. 1996. Influence of bacterial lipopolysaccharides on liposome-mediated transfection. Qiagen 4:89.

19.Wicks, I.P., M.L. Howell, T. Hancock, H. Kohsaka, T. Olee and D.A. Carson. 1995. Bacterial lipopolysaccharide copurifies with plasmid DNA: implications for animal models and human gene therapy. Hum. Gene Ther. 6:317-323.

Received 7 February 2000; accepted 4 May 2000.

Address correspondence to:

Dr. Donna K. Fox

Life Technologies, Inc. 9800 Medical Center Drive Rockville, MD 20850, USA e-mail:dfox@lifetech.com 